\title{
sciendo
}

Transport and Telecommunication, 2019, volume 20, no. 1, 62-73

Transport and Telecommunication Institute, Lomonosova 1, Riga, LV-1019, Latvia

DOI 10.2478/ttj-2019-0006

\section{SECA REGULATORY IMPACT ASSESSMENT: ADMINISTRATIVE BURDEN COSTS IN THE BALTIC SEA REGION}

\author{
Eunice O. Olaniyi ${ }^{1}$ and Gunnar Prause ${ }^{1,2}$ \\ ${ }^{1}$ School of Business and Governance, Tallinn University of Technology \\ Akadeemia tee 3, 12618 Tallinn, Estonia \\ eunice.olaniyi@taltech.ee \\ ${ }^{2}$ Wismar Business School, Wismar University \\ Philipp-Müller-Str. 14, 23966 Wismar, Germany \\ gunnar.pruase@taltech.ee
}

\begin{abstract}
After three years of $0.1 \%$ Sulphur limit of the Sulphur Emission Control Area (SECA) enforcement, empirical results have shown that the fears that SECA regulation would be a disadvantage for the Baltic Sea maritime sector are unfounded. Results have also shown commendable compliance rate and improved environmental conditions for the BSR. Nonetheless, there is still a need to clear the air regarding the costs information obligations that are required from maritime actors regarding their compliance activities. These activities are arguably obviously needful but could also lead to an unintended increase of costs of regulations.

Using a BSR-wide survey and case studies, the paper identified SECA information obligations related to the shipowners from shipping line whose vessels ply the SECA waters. The authors further evaluated the costs of the administrative burden related to these tasks.

The results show that the administrative burden for SECA regulations is different for shipowners and maritime authorities.
\end{abstract}

Keywords: SECA Regulations, Administrative Burden, Standard Cost Model, Clean Shipping, BSR, EnviSuM

\section{Introduction}

Global economic and social development has stimulated the creation of different rules and regulations on the advancement of all sectors. Most of these regulations encompass limitations or reduction of any activity that tends to affect the environment negatively (Wiśnicki et al., 2014).

The shipping sector is one that has received a lot of attention in recent years owing to the significant amount of pollution its activities releases to the environment. Some of these pollutants include CO2, SOx, ODS, VOC and NOx and are very negative to health (Unctad, 2015; Jiang et al., 2014). Until recently, bunkering fuel was predominantly heavy fuel oil (HFO) which has a high concentration of sulphur and dangerous to human health. To protect the environment and reduce the introduction of this dangerous substance, IMO (International Maritime Organization) began an enforcement regime by strategically creating the Sulphur Emissions Control Areas (SECA) in the sixth annexe of the MARPOL (International Convention for the Prevention of Pollution from Ships) Convention of the IMO where ships cannot use fuel with high sulphur concentrates. Furthermore, to protect its citizens and to reduce fatality from air pollution the European parliament embraced and adapted this international law in the EU Directive 1999/32/EC. Consequently, by January 2015, the European Parliament established a new SECA law enforced that enforces ships in Northern Europe including the Baltic Sea, to use fuel not more than $0.1 \%$ sulphur concentration (IMO, 2013).

The sulphur regulations gained increased global interest when in October 2016, the Marine Environment Protection Committee (MEPC) decided to drastically reduce SOx ship emissions in nonSECA worldwide from 3.5\% to $0.5 \%$ from 2020 (IMO, 2014; 2016; EU, 2015).

As new laws and regulations are made, by default, there are imposed burdens on people or authorities that are directly and indirectly involved and the most conclusion is that the costs of the regulations will automatically trickle down to the end users. (EfficienSea2, 2016). Furthermore, since marine fuel accounts for approximately $60 \%$ of the voyage costs, the impact of the SECA regulations will be crucial to the shipping stakeholders. This is why in 2015 , the European Union approved in the 
framework of the BSR Interreg Programme - EnviSuM (Environmental Impact of Low emission Shipping Measurements and Modelling Strategies) project to evaluate the technical efficiency and the socio-economic impact of sulphur regulations solutions in the BSR. Among these tasks is the analysis of the administrative costs of the SECA regulations on maritime stakeholders. These are costs incurred from information requirements that must be compiled, stored and/or submitted to public agencies or third parties.

The Standard Cost Model (SCM), originally developed in the Netherlands, as a commonly accepted policy approach for the quantification and aggregation of the administrative burden for a company (Charité et al., 2015) will be used and is based on the categorisation of impacts suggested by Renda et al. (2013). The study will include internal and external costs (if any) of each activity related to the data requirement that links to an information obligation of the SECA regulations or the amendments as they are adopted by maritime businesses in the BSR.

The work addresses the research question of what information obligations are related to the SECA regulations. How to assess the SECA-related administrative burden of the maritime sector in BSR? What are the impacts of this regulatory information obligation to these actors? The research activity involves a BSR-wide survey, secondary data analysis, expert interviews and case studies from shipping companies and maritime public authorities. The discussion focuses on the identification of administrative burdens imposed by the SECA regulations BSR as well as on the quantification of changes in the administrative processes of the maritime business for complying with the regulations. This study is important for sustainability and future policy deployment in the BSR.

The paper is organised as follows: the next section is the literature background studies SECA and regulations costs. Then, the system of methods used for this research is described followed by the analysis of the primary and secondary data, which is complemented, by expert interviews and a case study. The final section summed up the study.

\section{Costs of Regulations and the Administrative Burden}

The rationale behind governmental policies and regulations is often scrutinised, challenged, and never received with open arms. A case in point is a portion of the endogenous growth theory that argues that regulations most of the time result to economic deflators such as high tax rates, avoidable investments, unnecessary price hikes and negative markets adaptations that leads to sub-optimal investments (Barro, 1991). Solow (1994) also questions the cost-effectiveness of lowering the productivity and entrepreneurial activities of companies through regulations that end up negatively affecting the economic growth of a nation. In the same vein, Jaffe et al. (1995) reasoned that regulatory decisions can be timewasting and often followed by endless litigations or some endless legal battles that could further introduce excessive financial obligation they termed "transaction costs". At the introduction of new regulations or their build-ups, affected companies typically react through new strategies for innovation and research. They sometimes invest in expensive machinery upgrade (Bourlès et al., 2013) which is why Martin and Sunley (1998) insisted that the excessive influence of regulations on investments choices could eventually lead to waste on the long-term because these regulations are sometimes reversed, changed or replaced. The new Institutional Economics theory also assumes that institutions i.e. active rules such as regulations control the economic development of any country (Coase, 1998) thus, expensive transaction costs could lower the productivity of affected companies (Rebelo, 1991).

However, Olaniyi and Prause (2016) rebutted these claims by insisting that innovative activities that ensued from regulatory demand are important drivers of economic development. Solow (1994) further clarified that even if regulation brings some sort of alteration, they can be used as harmonized disruptive innovations that every economy depends on. More so, investments in knowledge generation like R\&D often create or increase productivity and as Hunke and Prause (2014) pointed out following sustainability rules can also improve the business performance. Furthermore, according to Olaniyi and Reidolf (2015), economic competitiveness depends on strong interconnectedness of research, innovations and the players of a particular industry. In other words, when businesses are forced to make regulatory-related changes or investments they, in turn, can improve their productivity thereby increasing their profit margin. Most importantly, the impact of governmental regulations can enforce much-needed stability linked to wider macroeconomic benefits like increased GDP, competitiveness and social benefits such as like protection of fundamental rights, social cohesion, international and national solidity (Renda et al., 2013). 
On another hand, from a pure economic standpoint, regulations related costs are long-termed investments for all involved and companies are largely affected by every category of costs which explains why the impact of sustainable transportation and green supply chain management are actively deliberated upon by different related stakeholders so that before the take-off of the SECA regulations in the BSR in 2015, the possible alterations in the shipping industry maritime stakeholders in BSR was intercalated in every related platform and at every opportunity (Prause and Hunke, 2014).

Cost is "any item that makes someone worse-off, or reduces a person's well-being", which includes forgone opportunities (Renda et. al., 2013) and according to OECD (2005), costs from regulations can be divided into direct financial costs and compliance costs. The financial costs as the sum of the Capital costs (CAPEX) and Operation costs (OPEX). CAPEX are acquisitions or upgrades of physical assets such as property, industrial buildings or equipment or, investment merge with operating and maintenance costs which is an ongoing cost for running a product, business, or system whenever a new legal provision changes the structure of the working capital. OPEX are annual expenditures on wages, energy, materials and supplies, purchased services, and maintenance of equipment (OECD, 2005). The compliance costs composed of both indirect costs and the administrative burdens (Wegrich, 2009). In other words, compliance costs are costs that businesses sustain simply because they are regulatory requirements.

The costs of SECA regulations was estimated to be high for the maritime stakeholders with much attention given to the shipowners whom they fear could as a result of their compliance investments transfer the costs increase to passengers and cargo owners (OECD/ITF 2016). A particular apprehension was on the regulation overall impact on global trade flow.

The reasoning out, in this respect, is on the likely possibility of an increased exportation to countries with less stringent rules, but the sulphur global cap of $0.5 \%$, which will affect everyone across the globe, aborted this discussion. However, it would be difficult to isolate singular outcome as positive since, in exportation, affected companies have to deal with the choice of foreign locations, different international and localised strategy, trade barriers, exchange rate fluctuations risks, political stability of foreign governments, as well as the risk of potential for opportunism and leakage of technology to local companies as among other factors (Eiteman et al., 2007). The possible "flight" of affected businesses to other countries with less stringent environmental laws will be a direct blow on the competitiveness of the inflow on foreign direct investment and any changes in investment patterns will ultimately affect exchange rate, investments plan as well as trade flows (Jaffe et al., 1995) in the EU.

In line with the afore-stated, Notteboom (2010), reckons that the possible consequences can be considered negative. In fact, the Institute of Shipping Economics and Logistics from Bremen (ISL, 2010) forecasted a disproportionally increase of maritime transport costs in SECA regions initiating a discussion of a cargo shift from sea to land transport that would result to shipping companies and ports losing handling volumes and income. Other discussions (i.e. AirClim, 2011; Wiśnicki et al., 2014; OECD/ITF, 2016) argued that the regulations would weaken the competitiveness of European maritime transport so that the implementation costs to the maritime sector would be between $€ 2.6$ billion and $€ 11$ billion by 2020. However, from research conducted since the introduction of the $20150.1 \%$ sulphur limit, the economic impact of the regulations are found to be negligible for most economic factors such as costs, pricing, FDI, cargo flows and modal splits in fact, the SECA has been reported to improve innovation and the branding of the BSR (Prause and Hunke, 2014; Olaniyi et al., 2018b; Olaniyi et al., 2018c).

Administrative burdens are costs incurred whenever a business is confronted by the necessity to provide information that arises by the operation of a law such as the SECA, which include obvious costs that can be objectively measured (e.g. costs of work, material or services such as bookkeeping etc.) (Wegrich, 2009). This information is irrelevant regarding an activity that a business is required to perform because of a regulatory information obligation if the business would also perform such acts in the absence of such obligation i.e. administrative activities that the businesses will continue to conduct if the regulations were removed (Renda et al., 2013).

At this point, is important to distinguish between indirect financial costs and administrative burden. Indirect costs are additional activities that have to do with the period spent by employees performing such administrative activities described, or from the outsourcing of those activities as a result of the regulation (e.g., fees for external experts, outsourcing costs, cost of acquisitions). Indirect costs can be substantive or charges. Substantive compliance costs include one-off costs and recurrent costs of carrying out the regulation while regulation charges are imposed payment of fees, levies, or taxes on related stakeholders. All of these are part of the administrative costs which are only done because the regulation requires it but will be discontinued if the regulation were to be removed (Wegrich, 2009). On the other hand, every activity that has to do with meeting these objectives from the time spent in researching, setting up of a department, time spent in seeking for loans as well as mundane activities like 
sending emails or receiving phone calls or data recording are all considered as administrative burdens. Others are tasks that require the release of a business of information to the public or government for official purposes such as monitoring (Renda et.al., 2013). The word "information obligation" are usually used in reference to any obligation imposed by a legal regulation (OECD, 2005).

Thus, to better address the needs of maritime stakeholders, it is also important to determine the complementary costs of the information obligations demanded from the shipping sector, which can be likened to unintentional consequences, or costs of regulations. Policymakers usually channel impact assessment by towards the reduction of compliance costs for affected companies.

\section{Methods}

The Standard Cost Model (SCM) is used generally for the calculation of administrative burden costs. Renda et al. (2013) defined the overall administrative burden per one information obligation as the sum of the costs of all activities necessary to meet the obligation multiplied by the number of repetitions of such activities during the given period shown in Figure 1.

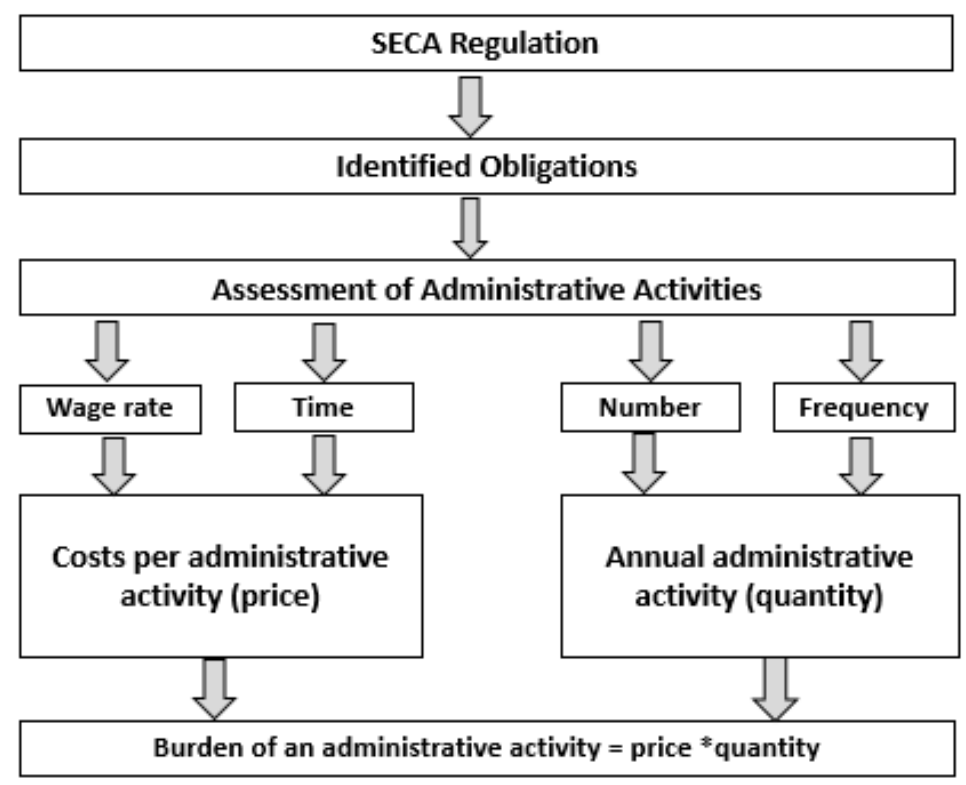

Figure 1: SECA Regulations Administration Burden Analysis Framework. Adapted from Renda et al. (2013)

The use of the SCM usually assumes some certain estimates; however, these estimates are carefully quantified and made even to ensure they are comparable with the ensuing tasks. SECA Administrative burden evaluation will involve 2 phases:

\section{Phase 1: Identification phase}

This is the preparatory stage where all information obligation imposed by the SECA regulations are identified along with their frequency i.e. the number of times they are required to be provided. The one-off information obligation is evenly spread over the period being analysed (one calendar year is used for this) - e.g. purchase of a special software like the emission measuring tool.

There is, however, an exception concerning one-off costs expended "once in life" (in case of a new regulation or a legislative amendment) that are included in full amount e.g. extraordinary report required by a new law (Wegrich, 2009). The second obligation identified are recurring tasks evenly spread over the period being analysed (one calendar year). This overall assessment will also include the differences in the present costs and the former related costs (OECD, 2005).

The next part of this stage will determine whether the tasks are performed by an employee or by an external expert. The costs calculations are determined by hourly pay rate either internally or externally.

\section{Phase 2: Measurement Phase}

Data collection, organisation and analysis methods are quantitative and qualitative as given by Marshal (1995 pp. 78-80); Mkansi et al., 2012). Klein and Myers (1999); Clark, Creswell, Green and 
Shope (2008) and O'Leary (2017) explained that this particular approach will augment, converge and substantiate the results outcome.

In the context of the EnviSuM project, a BSR-wide survey on the impact of SECA regulations was launched between autumn 2016 and spring 2017 in BSR with 122 responses. This survey was used to first narrow down administrative tasks and information obligations related to SECA across BRS. Face to face interviews, emails, skype calls were used to gather in-depth information from the experts. The interview lasted between 1-2 hours and took place between May and October 2018.

Three case studies were dedicated to shipping companies - as an inquiry with the aim of estimating an upper bound for the company's administrative costs of SECA since a case study investigates an individual, community or group to answer a specific question by seeking evidence that lies in the case setting (Gillham, 2000). Further still, records of the Environmental Inspectorate of the Republic of Estonia (Keskonna inspektsioon), the Port of Tallinn and the Maritime Administration (Veeteedeamet) were also examined to determine the compliance checks related to SECA regulations in the Estonian harbours. Data were collected between March and June 2018 from different records and the annual financial statements of the organisations.

\section{Findings and Discussion}

First, the results of the BRS-wide stakeholders' survey responses are presented to show a background information regarding the general impact of administrative burden on the maritime stakeholders in the BSR and expressed in percentages of the responses N (122); shipowners (38); Ports (24); maritime supply/services (39); others (21).

All respondents $(100 \%)$ are very familiar with the SECA regulations and its information obligation requirements. $67 \%$ have conducted SECA related training to raise the SECA awareness in their organisations. When asked if they or their staff have undergone one form of SECA training or another, $58 \%$ (22 respondents) of the shipowners says yes, 45\% (11 respondents) from the ports agreed, while more than half of the maritime supply/service providers (25) said they did not make any effort to increase the awareness among their staff. The departments that are most affected by the SECA regulations information obligations in the shipping companies are shipping, administration and finance/accounting departments. Activities that are most affected in the ports are port services and extension of port infrastructures and development. Again, more than half of the maritime supply/service providers (29) said they are only affected by their choice of investment regarding their SECA offerings.

\subsection{SECA Information Obligations Related to Shipowners}

From the survey and the interviews, the identified SECA information obligations related to the shipowners are recording into bunker delivery notes (BDN); time spent recording (fuel sample, scrubber emissions logbook \& waste disposal logbook (for ships using the scrubber technology), fuel switchover before entering SECA). Others are training and awareness of staff (also include hiring), off hiring days i.e. installations and maintenance, time to write applications for subsidies, grant and loans related to SECA investments and other specified obligations.

The estimation of the SECA - related administrative burden for shipowners represents a complex task due to different grades of fuels being used by the BSR shipowners as well as the different shipping patterns of the vessels. Cargo vessels ply between ports inside and outside SECA area and usually stay longer in ports for loading and discharging whereas ferries commute several times once or several times a day between two ports. Fortunately, the Helsinki Commission (HELCOM) regularly publishes reports on maritime activities in the Baltic Sea. In this respect, the latest HELCOM (2018) report revealed that around 8000 IMO registered ships visit the BSR annually whereas about 1500 IMO ships ply it an an given time. Nearly half of the ships are cargo vessels, ca. $20 \%$ are tankers and the rest are passenger ships, ferries, container ships and other vessels.

Expert interviews of shipowners revealed that the recording into a ship's emission logbooks takes place within a range of time usually between 10 minutes a day or $1 \mathrm{hr}$ within $21 / 2$ months to 3 months that represents information duty that started due to SECA regulations. In addition to that, a large number of shipping companies extended their staff training programs on ships due to SECA regulations but since these training only take place every one to two months, these training which is usually held for one hour are the only additional administrative burden of about 2 minutes the day spread evenly across the month. Finally, since the largest number of ships sail only within SECA regions, there are no notes required for 
recording timings for fuel switchover for these ships. The situation is however different for the ships that ply in and out of the SECA region.

\section{SECA Administrative Obligations Costs for Shipowners}

The calculation of the annual administrative burden for shipowners due to SECA regulations will be based on the assumption of average monthly staff costs of $5000 €$ in Denmark, Finland, Germany and Sweden as well as average monthly staff costs of $3500 €$ in Estonia, Latvia, Lithuania and Poland yielding an hourly rate for the inspections to about $26.88 €$. The daily plying 1500 ships in the BSR would not all ply in all the 365 days in a year because within this period are time used for repair, maintenance and offhire days with an assumption of 25 days per year so that each ship operates 340 days per year. By summing up these data, a daily administrative burden of 12 minutes per day is estimated and added to time spent on recording emission log books and SECA related training. All were evaluated by an hourly rate of $26.88 €$ and then multiplied by the annual number of operating ships in the BSR leading to the following Table 1:

Table 1. Calculation of SECA-related administrative burden for shipowners

\begin{tabular}{|c|c|}
\hline SECA-related Activities & Figure / Value \\
\hline \multirow{3}{*}{$\begin{array}{l}\text { Daily recording of emission logbook } \\
\text { Daily SECA - related additional training }\end{array}$} & 10 minutes \\
\hline & +2 minutes \\
\hline & 12 minutes \\
\hline \multicolumn{2}{|l|}{ Hourly rate } \\
\hline \multirow{3}{*}{$\begin{array}{l}\text { Number of daily plying ships in BSR } \\
\text { Operating days in BSR }\end{array}$} & $\begin{array}{l}\mathrm{x} 26.88 € / \mathrm{h} \\
=5.38 €\end{array}$ \\
\hline & x 1500 ships \\
\hline & x 340 operating days \\
\hline Annual administrative burden for shipowners & $2,743800 €$ \\
\hline
\end{tabular}

Table 1 shows that the total annual costs for shipowners in the BSR due to SECA-related administrative burden sum up to more than 2.7 million $€$. This figure seems to be very high but by calculating the annual administrative burden per ship the related costs are less than $2000 €$ per ship which represents a rather neglectable cost block compared to other cost categories in shipping like capital costs or fuel costs.

\section{Case Example 1: Scandlines Ferry Company}

The company "Scandlines" is owned by the private equity investor 3i Group and the parent company is Scandferries Holding ApS with a headquarter in Copenhagen and with a German subsidiary named Scandlines Deutschland GmbH situated in Hamburg and a Danish subsidiary named Scandlines Danmark ApS, situated also in Copenhagen.

Scandlines has a long history of ferry operation between Denmark, Germany and Sweden since 1872. Scandlines and Scandlines Helsingør-Helsingborg operate three ferry routes in the BSR. These routes are characterised by high capacity and frequency with 13 ferries that transported in 2017 with about 15 million passengers, 3.1 million cars, 1.1 million freight units and 56,000 busses recorded on three routes: Puttgarden-Rødby, Rostock-Gedser and Helsingør-Helsingborg. In 2017 Scandlines generated revenue of about $487 \mathrm{M} €$, a result before taxes of about $90 \mathrm{M} €$ and employed an average of 1,524 full-time employees (FTEs) in 2017 - 656 FTEs onshore and 868 FTEs at sea (Scandlines, 2017). The employees at sea are divided into maritime employees that represent the seamanlike crews running the ships and the client-based employees who are delivering services to the passengers comprising loading personnel, catering and client service at sea. Only the maritime employees are in touch with the SECA regulations whereas the client - based employees whose works are not directly affected by the SECA regulations.

The Scandlines consortium operates six hybrid ferries; four operating on Rødby-Puttgarden and two on Gedser-Rostock implying, Scandlines is the owner of the world's largest hybrid ferry fleet. A hybrid ferry combines traditional maritime fuel power with electric battery power to reduce fossil fuel consumption, carbon emissions and other pollutants. Scandlines uses fossil fuel also called Heavy Fuel Oil (HFO) and a scrubber that is installed on the vessels that clean the ship's emissions in compliance with SECA regulation. The Scandlines hybrid ferries are more eco-friendly when compared to conventional ferries because the hybrid ferry helps the company to reduce $\mathrm{CO}_{2}$ emissions up to about 
15.000 tons per year. The underlying technical concept of a hybrid ferry is that, in a normal service, only a part of the ferry's fuel engines are working at a load of $40-55 \%$ offshore and $8-10 \%$ when the ferry is in the ports whereas the engines work efficiently at a load of $85-90 \%$. By connecting the batteries to the fuel engines, the engines of the ship work would still work at this optimum load level (85-90\%) but at the same time store the surplus energy to the batteries on-board. The batteries then power the navigation in the port areas with deactivated fuel engines.

In response to the enforcement of the SECA regulations, the German Scanlines subsidiary, Scandlines Deutschland $\mathrm{GmbH}$, installed the scrubber technology on their three ships and started the construction of three hybrid ferries where two hybrid ferries operate currently on the Rødby-Puttgarden route and one on Gedser-Rostock route. For the coordination of the SECA activities in the German subsidiary, the company hired a dedicated SECA project manager/engineer who is located in Puttgarden and is responsible for all tasks related to scrubbers, batteries, hybrid technology, and waste/sludge management as well as for the SECA-related administrative burden. The total maritime service on the Rødby-Puttgarden ferries requires 14 sailors per ferry in two shifts every week whereas the seamanlike operating the German Rostock - Gedser ferry requires two shifts of 16 seamen. In addition to that, the SECA project manager is also responsible for the waste management on the Danish Rødby-Puttgarden ferries and he partly supervises about 7 technicians in Puttgarden and Rostock who are also contributing partly to SECA tasks.

By taking into account the SECA dedicated activities, the project manager in Puttgarden delivers i.e. an estimated range of admin time, frequency, wage range and the total maritime employees (Table 2) in the German Scandlines ferries, the administrative burden of the Scandlines is analysed.

Table 2. Number of SECA-Related Employees in Scandlines

\begin{tabular}{|l|c|}
\hline Activities Onboard Ferries & Number of Employees \\
\hline 2 shifts on 2 Puttgarden ferries with 14 seamen & 56 seamen \\
\cline { 2 - 2 } 2 shifts on Rostock ferry with 16 seamen & 32 seamen \\
\cline { 2 - 2 } Technicians \& Waste Management (30\%) & 2 persons \\
\hline Total & 90 employees \\
\hline
\end{tabular}

The relationship of one additional SECA project manager for ca. 90 SECA-related workplaces in Scandlines revealed an additional administrative burden of less than $2 \%$ when the total number of employees are considered. Consequently, the SECA - related administrative costs for the German Scandlines subsidiary could be estimated to be around $1 \%$ with an upper bound of $2 \%$. A view into the financial report of Scandlines Company for 2017 shows that already, the change in staff costs between 2016 and 2017 were about $4 \%$ on the base of about 1500 employees so that the administrative burden for SECA regulations in the company is negligible. This result fits the findings of other SECA related research on the economic impact of the SECA regulations on maritime stakeholders in the BSR (i.e. Olaniyi et al., 2018a; 2018b; 2018c).

Furthermore, the comparison of Scandlines administrative activities before and after SECA revealed very little change. The recording into the ship's emission log books which was not done before SECA now takes about 10 minutes on a daily bases. The filing of bunker delivery notes (BDN) remains the same as before SECA, takes only 10 minutes and done only once a month (i.e. $2 \mathrm{~h} /$ year). There were no recordings on SECA emission note before the regulation, but it now takes about 10 minutes daily (i.e. $71.4 \mathrm{~h} /$ year or 3 days/year).

A notable change was due to the maintenance of the scrubbers, and even though the scrubber maintenance is not an administrative burden in itself, this activity takes a day every month translating to one off-hiring day every month since SECA translating to the company earning of a whole day. Another significant change is the staff training and awareness activities, which now takes place one hour every month (i.e. $12 \mathrm{~h}$ /year) as opposed to the $15 \mathrm{mins}$ every 2 months before SECA. Since their ships sail only on SECA, there were no recording timings for fuel switchover. Apart from caustic soda used for the scrubber system, no additional external goods are purchased regularly.

\section{Case Example 2: Euroafrica Shipping Lines}

The EuroAfrica shipping line is a private polish owned shipping company that has been operating for about 60years. The shipping line is a part of ESL Hass Holding Group that is into other businesses such as industrial construction, housing development and building. Euroafrica operates two successful 
shipping operations, ferry and cargo services within Europe (UK, Sweden and the >Baltic) and conventional cargo services worldwide but mostly to West Africa. Their operational activities can be split into $35 \%$ within SECA and $65 \%$ outside SECA or more, but usually around this range. The headquarters is located in Szczecin, Poland.

Their fleet of geared multipurpose vessels is used to transport passengers and a wide range of commodities like general cargo, heavy lifts, project cargo and bulk cargo. As the only carrier that provided cocoa beans to the Baltic, Tallinn in particular, Euroafrica can be called the cocoa distribution specialist. Because of their cocoa technology and storage reputation, they particularly pay attention to temperature and ventilation condition of any vessel they acquire.

At the beginning of SECA, in order to comply, Euroafrica decided to use the low sulphur fuel and the hybrid ultra-low sulphur fuel for their ships. This decision was made easier because the company usually purchase used vessels, thus retrofitting with abatement technology like the scrubber would not be reasonable since the scrubber would normally then have a longer lifespan than their vessels. Using an alternative source of energy is also out of the question because LNG retrofit is very expensive. Since all their ferries operate within SECA, the company uses only the ultra-low sulphur fuel oil (ULSFO). In this situation, at the start of the SECA regulations, the only costs incurred was a one-off cost of having to flush out all the old HFO from the engine to ensure only compliance with the stipulated new law.

However, because they also operate outside the SECA, Euroafrica uses the HFO and switch to the low sulphur fuel on their approach to the SECA. To reduce the costs of energy, the speed of the vessel within the EU and SECA is reduced to ensure they consume less fuel. Fuel consumption is monitored through a friendly software that informs the captain about the voyage economy. Because only use low sulphur fuel within SECA, Eurafrica bunkers with only two specific British partners so they hardly take samples of their fuel for testing since they do not bunker worldwide trusting their source the fuel. As a result, most SECA administrative burden is removed. The number of their maritime are similar to Sandlines, however, the difference is that Euroafrica does not directly hire ship crew but contracted this activity out to a third party.

When approaching a SECA region, the ETA to the SECA region border is calculated to estimate the required switchover time. This process takes place over a period 2 hours of system monitoring to ensure hitch-free switch. The recording time in the logbook is different and depends on the vessel. This is discussed in the next section.

\section{Case example 3: Container Ships operating between SECA and Asia/Africa}

Compliance situations are somewhat different for container ships that go in and out of SECA. This time around interviews with ship captains and the chief engineers of these vessels showed that their SECA information obligation can be divided into three; namely recording into the SECA book, oil recording/engine log book and the internal training of crew. Because they operate outside SECA, their major SECA compliance strategy is to use the HFO outside the SECA and change to low sulphur fuel oil when they approach SECA and are within the SECA territory.

SECA Book: The SECA book is kept by the chief engineer to keep records of fuel change during switching of fuel. It consists of records of fuel sample, bunkering procedures (especially for those that bunker fuel worldwide, plan of fuel tanks and entry/exit records to document entry into and exit times in and out of SECA. Recoding all these activities into the SECA book takes the chief engineers about two hours for each voyage which normally happens 4-5 times a year. Taking the upper band would mean 10 hours of recording into the SECA book yearly. Spread into a year of 340 days would mean approximately 2 minutes a day.

Oil recording book/Engine logbook: In order to comply with SECA regulations as well as ensure costs saving, a lot of time is spent into bunkering planning which is regarded as additional regulation costs. Further, bunkering increased after SECA because of the need to buy different grades of fuel i.e. high sulphur fuel $(3.2 \%$ or $2.2 \%$ grade for non-SECA trips) and low sulphur fuel $(\leq 0.1 \%$ grade for SECA trips). This situation has increased the entry times for fuel and cylinder lubrication into the oil recording/engine log book considerably. Sometimes there are up to 4 grades of fuel. The activity known to have taken about $1 \mathrm{hr} 30 \mathrm{~min}$ per voyage has increased by at least $30 \mathrm{mins}$ since SECA for every bunkering resulting to additional $2 \mathrm{hrs} 30 \mathrm{~min}$ increase for a year (if bunkering or voyage is made 5 times a year). Depending on the fuel consumption or storage facility of the vessel, bunkering frequency can be more. For example, a smaller vessel can bunker fuel every month to lead to about 12 times a year. For this type of vessel, the number of entries into the oil /engine book will be more. 
Internal training: For every ship berth or bunkering, the vessel has to change its crew and as a result, the chief engineer and/or the captain spends considerable time to walk the new ship crew through the changeover process and procedure which usually takes about an hour or more for each voyage/bunkering. Subsequently a 5 times a year voyage will yield about $1 \mathrm{~min} /$ day training through the year.

The three cases discussed suggest that administrative burden related to SECA regulations is neglectable and ranges around $1 \%$ with an upper bound of $2 \%$ in all cases, which is in consonance with the previous findings of the EnviSuM project that until now, the impact of the SECA regulation has not been significant.

\subsection{Overall SECA Obligation of Maritime Authorities in the BSR}

Administrative tasks for maritime authorities in the BSR are mainly related to compliance checks of ships in national ports. The majority of the compliance checks are executed in the frame of port state controls of national maritime authorities which comprise checks of all six MarPol issues. All port state controls with European Union are inserted in the THETIS-EU databank at the European Maritime Safety Agency (EMSA) located in Lisbon. The report of the European Commission on implementation and compliance with the sulphur standards for marine fuels reveals a total number of MarPol VI inspections in the Baltic Sea and shows the following table as reported by HELCOM (2018):

Table 3. Number of MarPol VI inspections in BSR

\begin{tabular}{|l|c|cc|}
\hline Year & Number of inspections & \multicolumn{2}{|c|}{ Number of Non-compliance } \\
\hline \multirow{2}{*}{2015} & 1903 & 73 & $(3.8 \%)$ \\
\cline { 2 - 4 } 2016 & 1975 & 71 & $(3.6 \%)$ \\
\cline { 2 - 4 } 2017 & 1972 & 45 & $(2.3 \%)$ \\
\hline Average & $\mathbf{1 9 5 0}$ & \multicolumn{2}{|}{} \\
\hline
\end{tabular}

Table 3 highlights the high compliance rate, which improved over the last three years and reached about $97 \%$ in BSR. The MarPol VI related issue is only in one part and the expert interviews revealed an average time consumption for a MarPol VI inspection of 4 hours that composes of 1-hour preparation time, 2 hours on-board inspection time and 1-hour post-check time including the entry of the results of the inspection into the THETIS-EU database of EMSA. Thus, the annual time for MarPol VI inspections in BSR sums up to a total number of 1950 hours. Like in the case of the calculation of the administrative burden of shipowners, we assume an average monthly staff cost of $5000 €$ in Denmark, Finland, Germany and Sweden as well as average monthly staff costs of $3500 €$ in Estonia, Latvia, Lithuania and Poland. The calculations yield an hourly rate for the inspections of about $26.88 €$, i.e. the total annual administrative burden for the inspection of SECA regulations for the EU Maritime Authorities in the BSR yield $209625 €$.

In addition to the annual administrative burden, the costs for fuel sample testing have to be calculated. Unfortunately, the existing data does not explain the number of taken and analysed fuel samples but according to the EU regulations $40 \%$ of the MarPol VI inspections have to be linked to fuel sample tests, i.e. 789 fuel samples can be assumed to be tested annually in the BSR (EU, 2015). Expert interviews revealed that one fuel testing costs about $60 €$ yielding additional costs of $46800 €$ have to be added to the administrative burden of the Maritime Authorities. By summing up the two results, the total SECA-related administrative burden per year for all EU maritime authorities is about $260000 €$.

Further research shows that beyond on-board inspections, other activities are part of the enforcement of SECA regulations. One important measure is the installation of sniffing stations in special places like the bridges of ports to detect non-compliant vessel. Here, the average price for the installation of one fixed site sniffing station is about $140000 €$ but it is not possible to count the current number of fixed sniffing site except the well-known places like Öresund bridge, Great Belt bridge or in inlet channel in Göteborg BSR (Fung, 2016). However, expert interviews within the EnviSuM project revealed additional sniffing sites at Kiel and at upcoming places like Rostock.

\section{Case Example: Estonia - Port of Tallinn and the Maritime Administration}

The Environmental Inspectorate of the Republic of Estonia (Keskonna inspektsioon), the Port of Tallinn and the Maritime Administration (Veeteedeamet) were considered in order to investigate the compliance checks of SECA regulations in Estonian harbours and for maritime fuel suppliers. The 
investigations revealed that ships fuel samples were analysed while the ships stayed in the port, logbooks were also checked. However, the activities did not comprise direct exhaust gas measurements or sampling. In 2015, the sulphur content checks were of top priority for the Keskonna inspektsioon so that 250 samples were planned for all the Estonian coastline port but only $222(90 \%)$ were checked. In the end, only eight non-conformities and 4 exceedances of norm sulphur content were found in the analysed samples and misdemeanour proceedings proceeded for 5 cases and 4 were executed and fined. Consequently, due to the low number of violations, from 2016, a total number of 150 samples were planned and 128 were executed (85\%). No violations were detected in 2016 so that in 2017, the priorities for inspections have changed and in total only further 100 samples are planned and again no violations were detected.

Thus, by assuming half a day of work per MarPol VI inspection including fuel sampling, then less than one person is involved in the inspection work and by keeping under an account that the costs for fuel sample testing in Tallinn range around $50 €$ per sample. The SECA - related administrative burden in the case of Keskonna inspektsioon can be evaluated to be less than $1 \%$ for the institution. Additionally, between 2015 and 2017 the number of employees in Keskonna inspektsioon was reduced from 192 to 176 despite the fact that additional SECA inspections were added to the task list and it seems that the $1 \%$ seems to be an upper bound for SECA - related tasks of Keskonna inspektsioon (2017). This case is another confirmation of the findings from other maritime sectors including the considered cases of the shipping companies.

\section{Conclusion}

The objective of the study was to assess the general SECA-related administrative burden of the maritime sector in BSR, identify the information obligations related to the SECA regulations for the shipowners and identify the change impacts of the SECA regulation administrative burden to shipowners and maritime public authorities.

The results actually show that the administrative burden for SECA regulations is different for ship owners and maritime authorities. The annual administrative burden for ship owners sums up to about 2.7 million $€$ whereas the additional administrative costs for all maritime authorities in the BSR is only about $260000 €$. Despite the fact that total costs for ship owners are about 10 times higher than those for maritime authorities a more detailed consideration shows that on a ship level, the administrative burden is negligible with only about $2000 €$ per year. These results fit the findings of other SECA related research that the ex-ante expectations of SECA impact on maritime business in BSR were overestimated compared to the trifling effects that appeared after 2015.

A particular respondent says, "It is hard to notice the administrative burden of SECA - except for the maintenance - because there are different fragments of tasks to fulfil and each of them takes only a little time on a normal operation but in sum could be time-consuming". If this is so, then the question will be how expensive can "time-consuming" be. Leading to the next stage of this study, which will involve the calculations of the cost-benefit analysis of the SECA regulation on a holistic level taking into consideration the socio-economic aspect.

\section{Acknowledgements}

The authors thank the European Regional Development Fund in the frame of the BSR Interreg programme who sponsors the EnviSuM project

\section{References}

1. AirClim (2011) Air pollution from ship. Air Pollution \& Climate Secretariat Seas at Risk Bellona Foundation, North Sea Foundation Transport \& Environment European Environmental Bureau. https://www.transportenvironment.org/publications/ air-pollution-ships-0, last accessed 2016/05/21.

2. Barro, R.J. (1991) Economic growth in a cross-section of countries. Quarterly Journal of Economics, 106:40755.

3. Blind, K. (2012) The influence of regulations on innovation: A quantitative assessment for OECD countries. Research Policy, Vol. 41, No. 2, pp. 391-400.

4. Bourlès, R., Cette, G., Lopez, J., Mairesse, J. and Nicoletti, G. (2013) Do product market regulations in upstream sectors curb productivity growth? Panel data evidence for OECD countries. Review of Economics and Statistics, Vol. 95, No. 5, pp. 1750-1768. 
5. Charité, D., Kirkegaard, P., Svensson, G. and Greve, J. (2015) Das Standard-Kostenmodell Konzept zur Definition und Quantifizierung des Verwaltungsaufwandes für Unternehmen durch staatliche Regulierung.

6. Clark, V.L.P., Creswell, J.W., Green, D.O.N. and Shope, R.J. (2008) Mixing quantitative and qualitative approaches. Handbook of emergent methods, 363.

7. Coase, R. (1998) The new institutional economics. The American Economic Review, Vol. 88(2), pp.72-74.

8. EfficienSea2 (2016) Report on the available technologies and sensors that can be utilized in the new system and on a business model on incentives for monitoring and enforcement. http://efficiensea2.org/publications/. Accessed on 12/08/2016.

9. Eiteman, D.K., Stonehill, A.I., and Moffett, M.H. (2007) Fundamentals of multinational business finance. Addison-Wesley.

10. EU Directive (2014) 2014/94/EU of the European Parliament and of the Council of 22 October 2014 on the deployment of alternative fuels infrastructure. Official Journal of the European Union, L307/1-20

11. European Union (2015) Commission implementing the decision (EU) 2015/253 of 16 February 2015 laying down the rules concerning the sampling and reporting under Council Directive 1999/32/EC as regards the sulphur content of marine fuels, February 17, 2015, - http://eur-lex.europa.eu/legalcontent/EN/TXT/?uri=CELEX:32015D0253, access on 12/02/2018.

12. European Union (2018) Report on implementation and compliance with the sulphur standards for marine fuels set out in Directive (EU) 2016/802 relating to a reduction in the sulphur content of certain liquid fuels, Brussels, 16.4.2018, COM (2018) 188 final.

13. Fung, F. (2016) Enforcement of Fuel Switching Regulations - Practices adopted in the US, EU and other regions, and lessons learned for China. NRDC.

14. Gillham, B. (2000) Case study research methods. Bloomsbury Publishing

15. HELCOM (2018) Maritime Assessment 2018, "HELCOM Assessment on maritime activities in the Baltic Sea 2018", Baltic Sea Environment Proceedings No.152. Helsinki Commission, Helsinki. 253pp.

16. Hunke, K., Prause, G. (2014) Sustainable supply chain management in German automotive industry: experiences and success factors. Journal of Security and Sustainability Issues, 3 (3), 15-22.10.9770/jssi.2014.3.3(2).

17. IMO (2013) Sulphur oxides (SOx)—Regulation 14. http://www.imo.org/OurWork/Environment/ Pollution Prevention/AirPollution/Pages/Sulphur-oxides-(SOx). Regulation-14.aspx. Accessed 201609-20.

18. IMO (2014) Third IMO GHG Study, International Maritime Organisation, London, UK (2014).

19. IMO (2016) IMO sets 2020 date for ships to comply with low sulphur fuel oil requirement. Press briefing release, - http://www.imo.org/en/MediaCentre/PressBriefings/Pages/MEPC-702020sulphur.aspx. Accessed 2016/11/30.

20. ISL (2010) Reducing the sulphur content of shipping fuels further to $0.1 \%$ in the North Sea and Baltic Sea in 2015: Consequences for Shipping in this Area. Commissioned by the German Shipowners Association and Association of German Seaport Operators. Institute of Shipping Economics and Logistics, Bremen.

21. Jaffe, A.B., Peterson, S.R., Portney, P.R. and Stavins, R.N. (1995) Environmental regulation and the competitiveness of US manufacturing: what does the evidence tell us? Journal of Economic Literature, Vol 33, No. 1, pp. 132-163.

22. Jiang L., Kronbak J., Christensen L.P. (2014) The costs and benefits of sulphur reduction measures: Sulphur scrubbers versus marine gas oil. Transportation Research Part D, Vol. 28, pp. 19-27.

23. Keskonna inspektsioon (2017) - www.kki.ee, Tallinn, accessed on 27/06/2018.

24. Klein, H.K. and Myers, M.D. (1999) A set of principles for conducting and evaluating interpretive field studies in information systems. MIS Quarterly, 67-93.

25. Marshall, C. (1995) Designing qualitative research. Thousand Oaks, Calif.; London: Thousand Oaks, Calif.; London: Sage.

26. Martin, R. and Sunley, P. (1998) Slow convergence? The new endogenous growth theory and regional development. Economic geography, 74(3), 201-227.

27. Mkansi, M., Acheampong, E.A., Qi, B. and Kondadi, K.R. (2012) Research philosophical debates and classifications: Students' dilemma'. In Proceedings of the 11th European Conference on Research Methods in Business and Management, University of Bolton, Bolton, UK, pp. 277-284. 
28. Notteboom, T. (2010) The impact of low sulphur fuel requirements in shipping on the competitiveness of roro shipping in Northern Europe. WMU Journal of Maritime Affairs, Vol. 10, No. 1, pp. 63-95.

29. O'Leary, Z. (2017) The essential guide to doing your research project. Los Angeles, [Calif.]; London: Los Angeles, Calif.; London: SAGE.

30. OECD (2005) Network, Standard Cost Model. International standard cost model manual. Measuring and reducing administrative burdens for businesses.

31. OECD/ITF (2016) Reducing Sulphur Emissions from Ships: The Impact of International Regulation. - http://www.itf-oecd.org/reducing-sulphur-emissions-ships-impact-international-regulation accessed on $10 / 06 / 2016$.

32. Olaniyi, E. O. and Reidolf, M. (2015) Organisational Innovation Strategies in the Context of Smart Specialization. Journal of Security and Sustainability Issues, Vol. 5, No. 2, pp. 213-227.

33. Olaniyi, E., Prause, G. and Boyesen, J. (2018b) The impact of SECA regulations on clean shipping in the BSR. In: Ölçer, A, Kitada, O., Dalaklis, D., Ballini, F., (eds.) Trends and Challenges in Maritime Energy Management book series of WMU Studies in Maritime Affairs. Vol 6 (1) DOI 10.1007/978-3319-74576-3. Springer international publishing.

34. Olaniyi, E.O. and Prause, G. K. (2016) Baltic-Russian Innovation Cooperation in the Context of EU Eastern Partnership. In T. Kerikmäe \& A. Chochia (Eds.), Political and Legal Perspectives of the EU Eastern Partnership Policy. Switzerland, Springer International Publishing, pp.257-279.

35. Olaniyi, E.O., Atari, S. and Prause, G. (2018c) Maritime energy contracting for clean shipping. Transport and Telecommunication, 19 (1), 31-44.10.2478/ttj-2018-0004 (2018).

36. Olaniyi, E.O., Gerber, P. and Prause, G. (2018a) Strategic Energy Partnership in Shipping. In: Kabashkin, I., Yatskiv, I., Prentkovskis, O. (Ed.). Reliability and Statistics in Transportation and Communication (102-111). Berlin: Springer (Lecture Notes in Networks and Systems; 36).

37. Prause, G., Hunke, K. (2014) Sustainable Entrepreneurship along green corridors. Journal of Entrepreneurship and Sustainability Issues, Vol. 1 (3), 124-133, 10.9770/jesi.2014.1.3 (1).

38. Rebelo, S. (1991). Long-run policy analysis and long-run growth. Journal of Political Economy, Vol. 99, No.3, pp. 500-521.

39. Renda, A., Schrefler, L., Luchetta, G. and Zavatta, R. (2013) Assessing the Costs and Benefits of Regulation. Brüssel: Centre for European Policy Studies. Online erhältlich unter - http://ec. Europa.eu/smart regulation/impact/commission_guidelines/docs/131210_cba_study_sg_final. Pdf, on accessed 01/06/2014.

40. Scandlines (2017) Annual Report, Copenhagen - https://www.scandlines.com/aboutscandlines/about-scandlines-frontpage/finance, accessed on 29/062018.

41. Solow, R.M. (1994) Perspectives on growth theory. The Journal of Economic Perspectives, Vol. 8(81) pp. $45-54$.

42. Unctad (2015) Legal Issues and Regulatory Developments Ship-source pollution and protection of the environment, - unctad.org/en/PublicationChapters/rmt2015ch5_en.pdf Feb 25, 2015 - Chapter 5: legal issues and regulatory developments.

43. Wegrich, K. (2009) The administrative burden reduction policy boom in Europe: comparing mechanisms of policy diffusion. Centre for Analysis of Risk and Regulation, London School of Economics and Political Science.

44. Wiśnicki, B., Czermański, E., Droździecki, S., Matczak, M. and Spangenberg, E. (2014) Sulphur Regulation-technology solutions and economic consequences for the Baltic Sea Region shipping market. In: Ernest Czermański (ed.) Institute of Maritime Transport and Sea-borne Trade, University of Gdańsk. 